IJAMSR 3 (8) www.ijamsr.com CrossRef: https://doi.org/10.31426/ijamsr.2020.3.8.3612

\title{
INDEFEASIBLE ROLE OF VITAMIN D IN COVID-19
}

\section{Payel Mukherjee ${ }^{1}$, Arindam Chakraborty ${ }^{2}$, Sunirmal Bhattacharjee ${ }^{3}$, Dr. Manas Chakraborty ${ }^{2}$}

${ }^{1}$ Department of Pharmaceutics, Gurunanak Institute of Pharmaceutical Science and Technology, West Bengal, India

${ }^{2}$ Department of Pharmaceutical Biotechnology, Calcutta Institute of Pharmaceutical Technology and AHS, West Bengal, India

${ }^{3}$ Department of Pharmaceutics, Bharat Pharmaceutical Technology. Agartala, Tripura, India

Email: pmukherjee832@gmail.com

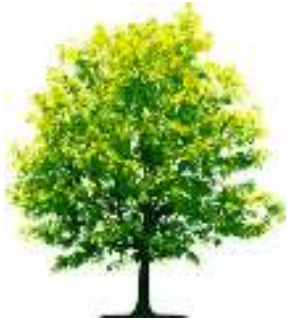

Keywords:

COVID-19, SARS-CoV-2, Socioeconomic Status, Vitamin D, Cathelicidins, Defisins, Acute Respiratory Distress Syndrome, 25(OH) D, Influenza, Pneumonia, Cytokines, Respiratory Tract Infections

\begin{abstract}
A B S T RA C T
We are going through a tough time. COVID-19 or SARS CoV-2 (Severe Acute Respiratory Syndrome Coronavirus 2) causes pandemic in the whole world. Apart from quarantine some health measures are desperately needed to be taken as well. Mortality from COVID-19 is higher in some countries than the others. Many factors are playing essential role in this disparity including elderly people in population, general health, quality and accessibility of healthcare, socioeconomic status and most importantly Vitamin D status in the population. In this article we will be giving insights to the roles of Vitamin D in reducing respiratory tract infection, knowledge about influenza and COVID-19 epidemiology and how Vitamin D can reduce the risk. Vitamin D can reduce the risk via several mechanisms such as inducing cathelicidins and defisins which can lower the rate of viral replication, reducing pro inflammatory cytokines concentration which can injure the lining of the lungs leading to pneumonia and increasing the anti-inflammatory cytokines concentration. Vitamin D can lower the risk of COVID-19 outbreak in winter when the concentration of 25 Hydroxy Vitamin D or $25(\mathrm{OH})$ D will be lowest. Deficiency of vitamin D can cause acute respiratory distress syndrome, increase fatality rate in aged people when $25(\mathrm{OH}) \mathrm{D}$ concentration is lower. So it is required to take 10,000 IU/d of Vitamin D3 to raise 25(OH) D for few weeks followed by $5,000 \mathrm{IU} / \mathrm{d}$. The concentration of $25(\mathrm{OH}) \mathrm{D}$ in the body should be higher than $40-60 \mathrm{ng} / \mathrm{ml}$ (100-150 nmole/L) to lower the risk of COVID-19.
\end{abstract}

Citation: Payel Mukherjee, Arindam Chakraborty, Sunirmal Bhattacharjee, Dr. Manas Chakraborty (2020). Indefeasible Role Of Vitamin $D$ In Covid-19. International Journal of Advanced Multidisciplinary Scientific Research (IJAMSR) ISSN:2581-4281, 3 (8), August 2020, Pp 41 - 47 
IJAMSR 3 (8) www.ijamsr.com CrossRef: https://doi.org/10.31426/ijamsr.2020.3.8.3612

\section{Introduction}

The novel coronavirus or COVID-19 previously known as 2019-nCoV is a global pandemic which is impacting the communities immeasurably ${ }^{[1]}$. Seasonal influenza has high rate of health burden. In one recent estimate it has been seen that 3,89,000 (ranges between 2, $94,000-5,18,000)$ deaths were happened with influenza during 2002 to 2011 period. During this period 2010 to 20199 - 45 million people affected by annual symptomatic illness resulting about 4 - 21 million medical visits, 1 , 40,000 - 8, 10,000 hospitalizations and about 23000 to 61000 deaths ${ }^{[2]}$.

In COVID-19 patients, SARS-CoV-2 virus binds to the infected patient's respiratory tract's angiotensin converting enzyme-2 or ACE-2 receptors to enter host cell ${ }^{[3]}$. At early stage protective immune response can eliminate the virus but later the immune responses should be improved. As the disease develops activated macrophages and type $1 \mathrm{~T}$ helper (Th1) immune cells start to release proinflammatory cytokines namely interleukin (IL)-1B and IL- 18 resulting in lung inflammation and fibrosis. Immunocompromised older patients are at high substantial risk. The main barrier for treating the disease is the knowledge gap on human immune response to SARS-CoV-2 ${ }^{[4,5]}$.

Vitamin D is a seccosteroid and has a wide range of immunomodulatory, antioxidant and anti-inflammatory antifibrotic activity. Vitamin $\mathrm{D}$ can inhibit the expression of inflammatory cytokines (IL-1 $\alpha$, IL-1 $\beta$, tumor necrosis factor $\alpha$ ). Overexpression of the Th1 cytokines can be associated by insufficiency of Vitamin D. Recent studies have shown that disease progression and increased mortality in patients with autoimmune liver disease were associated by severe Vitamin D deficiency $(<25$ $\mathrm{nmol} / \mathrm{L}^{[6]}$.

\section{High Risk Patients Of Covid-19 With Vitamin D Deficiency}

Patients with immuno deficiency and bronchiectasis and also older adults having mild to severe Vitamin D deficiency are more likely to get ill from COVID-19. Vitamin D plays an important role in diabetes mellitus and cardiovascular diseases. In obesity and smokers, Vitamin D deficiency is common, Studies have shown that in Chicago more than half COVID-19 cases and around 70\% COVID-19 deaths were observed in those who 
IJAMSR 3 (8) www.ijamsr.com CrossRef: https://doi.org/10.31426/ijamsr.2020.3.8.3612

are at the great risk for Vitamin D deficiency ${ }^{[7-}$ $\left.{ }^{11}\right]$.

Several environmental factors affect the formation of Vitamin D by sunlight such as seasonal variation in sun exposure, geographical latitude, air pollution, dark skin tone etc. In some studies, it has been seen that Vitamin D concentration are intended to be lower in high latitudes countries and high prevalence of vitamin D deficiency and insufficiency are reported for those affected $\operatorname{areas}^{[12-15] \text {. }}$

\section{Mechanisms Of Vitamin D To Reduce The Microbial Infections}

We know the basic metabolism and function of Vitamin D. Vitamin D3 is generally produced in the skin by UVB radiation reaction then it reached to the 7-dehydro-cholesterol of the skin followed by thermal reactions, then the Vitamin D3 or vitamin D taken orally is converted to $25(\mathrm{OH}) \mathrm{D}$ in the liver and then to the hormonal metabolite, $1,25(\mathrm{OH}) \mathrm{D}$ or calcitriol which is needed in the kidney and other organs. Most of the effects of the Vitamin D used to arrive when calcitriol enters to the nuclear Vitamin D receptor which is a DNA binding protein interacts with regulatory sequences near target genes and recruits chromatin active complexes which participate genetically and epigenetically in modifying transcriptional output ${ }^{[16,17]}$.

In many reviews it has been reported that Vitamin D can reduce the risk of viral infection. Vitamin D generally reduces the risk of microbial infection via several mechanisms categorized as: physical barriers, cellular natural immunity and adaptive immunity. Vitamin D helps to maintain tight junctions, gap junctions and adherens junctions (e.g., Ecadherin) ${ }^{[18] \text {. }}$

Vitamin D usually enhances the cellular innate immunity via induction of antimicrobial peptides; including LL-37, human cathelicidins, by 1,25 di-hydroxy-vitamin D and defisins ${ }^{[19]}$.

Vitamin D also enhance cellular immunity by reducing the cytokines storm induced by innate immune system. The innate immunity system usually generates the pro and antiinflammatory cytokines in response to the microbial infection. Vitamin D administration can reduce the pro-inflammatory cytokines expression and increase the anti-inflammatory cytokines expression. Vitamin $\mathrm{D}$ is a modulator of adaptive immunity, 1,25(OH)2D3 
IJAMSR 3 (8) www.ijamsr.com CrossRef: https://doi.org/10.31426/ijamsr.2020.3.8.3612

used to suppress the responses which is created by the helper T cell Type-I (Th1), by primarily repressing the production of inflammatory cytokines IL-2 and interferon-gamma (INF$\gamma)^{[20,21] .}$

Vitamin D supplementation can enhance the gene expression related to antioxidation (glutathione reductase and glutamate cysteine ligase modifier subunit). The increased production of glutathione usually spares the ascorbic acid use (Vitamin C), having antimicrobial activities and can prevent and treat COVID-19 ${ }^{[22]}$.

\section{Vitamin D And Respiratory Tract Infections}

Through several study reports it has been said that deficiency of Vitamin D is associated with viral respiratory tract infection and acute lung injury. Calcitriol, a Vitamin D agonist used to provide protection against acute lung injury by modulating the expression of members of the renin angiotensin system such as ACE-2 in lung tissue ${ }^{[23,24]}$.

The primary target of coronavirus is a type 2 pneumocytes and ACE-2 receptors are expressed highly on this cells. Surfactant level is decreased and surface tension in COVID-19 is increased by the impaired function of the type 2 pneumocytes. Vitamin $\mathrm{D}$ has the potential to reduce the surface tension in covid$19^{[25] .}$

Finally some studies have come up with some reports which have shown treatment with high dose of Vitamin D (i.e. 250,000 to 500,000 IU) is safe in critically ill and mechanically ventilated patients and also associated with shorter length of stay in hospital and improve the ability of the blood to carry the oxygen and increase the hemoglobin level. The risk of acute viral respiratory tract infection was reported to be less about twofold when the Vitamin D serum level $\geq 95 \mathrm{nmol} / \mathrm{L}$ ( hazard ratio $0.51 ; \mathrm{CI} 95 \%, 0.23-0.84 ; \mathrm{P}<0.0001)$ and in compared with patients with levels $<95$ nmole/L the sick days percentage was less about 5 times $(0.80 \% \text { vs } 3.9 \%, \mathrm{P}=0.02)^{[26,27] \text {. }}$

\section{Proposed Plan Of Action}

Till now no study has been established to measure Vitamin D level and Vitamin D treatment in COVID-19 patients. Vitamin D deficiency in elder people, smokers, patients having chronic diseases and in obese patients have high risk in COVID-19. It is necessary to measure the serum $25(\mathrm{OH}) \mathrm{D}$ levels in all in and out patients with covid-19 and in all the 
IJAMSR 3 (8) www.ijamsr.com CrossRef: https://doi.org/10.31426/ijamsr.2020.3.8.3612

\section{International Journal of}

Advanced Multidisciplinary Scientific Research (IJAMSR) ISSN:2581-4281

stages of the covid-19 disease to track the increasing level of $25(\mathrm{OH}) \mathrm{D}$ into the optimal range of 40 to $60 \mathrm{ng} / \mathrm{nL}(100-150 \mathrm{nmol} / \mathrm{L})$. Relationship between baseline Vitamin D and severity of the disease, platelet count, lymphocyte count, white blood cell count, serum-ferritin, albumin count, hospitalization, intensive care unit admission should be determined, which will help to discover the relationship between low Vitamin D level and risk of the disease ${ }^{[28] .}$

To increase the serum $25(\mathrm{OH})$ D level in patients with respiratory disease $(<50 \mathrm{nmol} / \mathrm{L})$, it is recommended to take Vitamin D supplementation of 50,000 IU twice a week (i.e. $100,000 \mathrm{IU}$ in total) ${ }^{[29]}$.

It is recommended that following 100,000 IU start dose, patient should continue the dose with 50,000 IU taken once a week for second and third week to increase the optimal level of serum $25(\mathrm{OH}) \mathrm{D}$. It is also suggested that the patient should be monitored to ensure that the circulating level of vitamin D in covid-19 patients are increasing and disease condition is improved $^{[30,31] \text {. }}$

\section{Conclusion}

Because of some knowledge barrier and lack of data, systematic management is given for COVID-19 patients with severe infection, like oxygen therapy, mechanical ventilation etc. but vitamin $D$ is very effective and easy way of administration. It will reduce the surface tension and expression of the inflammatory cytokines. Vitamin D supplementation would be very beneficial in COVID-19 patients as because it will elevate the serum $25(\mathrm{OH}) \mathrm{D}$ levels in the patients and improve the survival of the patients. As a summary, vitamin D is a very safe and noninvasive treatment for COVID-19 patients. It will reduce the risk of COVID-19 severity and mortality. So high dose of vitamin $\mathrm{D}$ treatment is very much needed and suggested. Although we are going through a very tough time but if we will use Vitamin D supplementation as a treatment for COVID-19, it will be very beneficial and helpful for the mankind as because Vitamin D is directly linked with the COVID-19 severity. 
IJAMSR 3 (8) www.ijamsr.com CrossRef: https://doi.org/10.31426/ijamsr.2020.3.8.3612

\section{International Journal of \\ Advanced Multidisciplinary Scientific Research (IJAMSR) ISSN:2581-4281}

\section{References}

1) Arindam Chakraborty., et al. "The Current Overview of COVID-19 Pandemic in India". Acta Scientific Microbiology 3.7 (2020): 52-55.

2) Zhu, N.; Zhang, D.; Wang, W.; Li, X.; Yang, B.; Song, J.; Zhao, X.; Huang, B.; Shi, W.; Lu, R., et al. A Novel Coronavirus from Patients with Pneumonia in China, 2019. $N$ Engl J Med 2020, 10.1056/NEJMoa2001017.

3) Paget, J.; Spreeuwenberg, P.; Charu, V.; Taylor, R.J.; Iuliano, A.D.; Bresee, J.; Simonsen, L.; Viboud, C.; Global Seasonal Influenza-associated Mortality Collaborator, N.; Teams*, G.L.C. Global mortality associated with seasonal influenza epidemics: New burden estimates and predictors from the GLaMOR Project. J Glob Health 2019, 9, 020421.

4) Hoffmann M, Kleine-Weber H, Schroeder $S$, Kruger N, Herrler T, Erichsen $S$, et al. SARS-CoV-2 Cell entry depends on ACE2 and TMPRSS2 and is blocked by a clinically proven protease inhibitor. Cell. 2020.

5) Conti P, Ronconi G, Caraffa A, Gallenga $C E$, Ross R, Frydas I, et al. Induction of pro-inflammatory cytokines (IL-1 and IL-6) and lung inflammation by Coronavirus-19 (COVI-19 or SARS-CoV2): antiinflammatory strategies. $J$ Biol Regul Homeost Agents. 2020; 34.

6) Cascella M, Rajnik M, Cuomo A, Dulebohn SC, Di Napoli R. Features, evaluation and treatment coronavirus (COVID-19). Treasure Island, FL: StatPearls; 2020.

7) Hughes DA, Norton R. Vitamin $D$ and respiratory health. Clin Exp Immunol. 2009; 158:20-5.
8) Amaya-Mejia AS, O’Farrill-Romanillos PM, Galindo-Pacheco LV, Vargas-Ortega $G$, Mendoza-Zubieta $V$, Del Rivero Hernandez $L G$, et al. Vitamin D deficiency in patients with common variable immunodeficiency, with autoimmune diseases and bronchiectasis. Rev Alerg Mex. 2013; 60:110-6.

9) Meehan $M$, Penckofer $S$. The role of vitamin $D$ in the aging adult. $J$ Aging Gerontol. 2014; 2:60-71.

10) Peterlik M, Cross HS. Vitamin D and calcium deficits predispose for multiple chronic diseases. Eur J Clin Invest. 2005; 35:290-304.

11) Dhaliwal $R$, Mikhail $M$, Feuerman $M$, Aloia JF. The vitamin $D$ dose response in obesity. Endocr Pract. 2014; 20:1258-64.

12) Kassi EN, Stavropoulos S, Kokkoris P, Galanos A, Moutsatsou P, Dimas C, et al. Smoking is a significant determinant of low serum vitamin $D$ in young and middle-aged healthy males. Hormones. 2015; 14:24550.

13) Yancy CW. COVID-19 and African Americans. JAMA. 2020.

14) Alzaman NS, Dawson-Hughes B, Nelson J, D'Alessio D, Pittas AG. Vitamin D status of black and white Americans and changes in vitamin $D$ metabolites after varied doses of vitamin D supplementation. Am J Clin Nutr. 2016; 104:205-14.

15) Wacker M, Holick MF. Sunlight and vitamin D: a global perspective for health. Dermatoendocrinol. 2013; 5:51-108.

16) Sajadi MM, Habibzadeh P, Vintzileos A, Shokouhi S, MirallesWilhelm F, Amoroso A. Temperature, humidity and latitude analysis to predict potential spread and seasonality for COVID-19. SSRN. 2020.

17) Holick, M.F. Vitamin D deficiency. $N$ Engl J Med 2007, 357, 266-281, doi: 10.1056/NEJMra070553. 
IJAMSR 3 (8) www.ijamsr.com CrossRef: https://doi.org/10.31426/ijamsr.2020.3.8.3612

18) Pike, J.W.; Christakos, S. Biology and Mechanisms of Action of the Vitamin D Hormone. Endocrinol Metab Clin North Am 2017, 46, 815-843, doi:10.1016/j.ecl.2017.07.001.

19) Beard, J.A.; Bearden, A.; Striker, $R$. Vitamin $D$ and the anti-viral state. J Clin Virol 2011, 50, 194-200, doi:10.1016/j.jcv.2010.12.006.

20) Hewison, M. An update on vitamin $D$ and human immunity. Clin Endocrinol (Oxf) 2012, 76, 315-325.

21) Chen, Y.; Leng, K.; Lu, Y.; Wen, L.; Qi, Y.; Gao, W.; Chen, H.; Bai, L.; An, X.; Sun, B., et al. Epidemiological features and timeseries analysis of influenza incidence in urban and rural areas of Shenyang, China, 2010-2018. Epidemiol Infect 2020, 148, e29.

22) Rossi, G.A.; Fanous, H.; Colin, A.A. Viral strategies predisposing to respiratory bacterial superinfections. Pediatr Pulmonol 2020, 10.1002/ppul.24699.

23) Liu, P.T.; Stenger, S.; Li, H.; Wenzel, L.; Tan, B.H.; Krutzik, S.R.; Ochoa, M.T.; Schauber, J.; Wu, K.; Meinken, C., et al. Toll-like receptor triggering of a vitamin $D$ mediated human antimicrobial response. Science 2006, 311, 1770-1773.

24) Hansdottir S, Monick MM. Vitamin D effects on lung immunity and respiratory diseases. Vitam Horm. 2011; 86:217-37.

25) Greiller CL, Martineau AR. Modulation of the immune response to respiratory viruses by vitamin D. Nutrients. 2015; 7:4240-70.

26) Rehan VK, Torday JS, Peleg S, Gennaro L, Vouros P, Padbury J, et al. 1Alpha, 25dihydroxy-3-epi-vitamin D3, a natural metabolite of 1alpha, 25-dihydroxy vitamin D3: production and biological activity studies in pulmonary alveolar type II cells. Mol Genet Metab. 2002; 76:46-56.
27) Han JE, Jones JL, Tangpricha V, Brown MA, Brown LAS, Hao L, et al. High dose vitamin $D$ administration in ventilated intensive care unit patients: a pilot double blind randomized controlled Trial. J Clin Transl Endocrinol. 2016; 4:59-65.

28) Sabetta JR, DePetrillo P, Cipriani RJ, Smardin J, Burns LA, Landry ML. Serum 25-hydroxyvitamin $D$ and the incidence of acute viral respiratory tract infections in healthy adults. PLoS ONE. 2010; 5:e11088.

29) Ekwaru JP, Zwicker JD, Holick MF, Giovannucci E, Veugelers PJ. The importance of body weight for the dose response relationship of oral vitamin $D$ supplementation and serum 25 hydroxyvitamin $D$ in healthy volunteers. PLoS ONE. 2014; 9:e111265.

30) Martineau AR, Nanzer AM, Satkunam KR, Packe GE, Rainbow SJ, Maunsell ZJ, et al. Influence of a single oral dose of vitamin $D$ (2) on serum 25-hydroxyvitamin D concentrations in tuberculosis patients. Int J Tuberc Lung Dis. 2009; 13:119-25.

31) Kimball SM, Mirhosseini N, Holick MF. Evaluation of vitamin D3 intakes up to 15,000 international units/day and serum 25hydroxyvitamin $D$ concentrations up to $300 \mathrm{nmol} / \mathrm{L}$ on calcium metabolism in a community setting. Dermatoendocrinol. 2017; 9: e1300213. 